\title{
半導体パッケージはんだ接続パッド引出し配線の疲労強度評価*
}

$$
\begin{aligned}
& \text { 中 康 } \text { 弘 }^{* 1} \text {, 矢 口 昭 弘*1 } \\
& \text { 木 本 良 輔*2, 三 輪 孝 }{ }^{*}{ }^{* 2}
\end{aligned}
$$

\section{Evaluation of Fatigue Strength of Wiring in Solder Joint Pads in LSI Packages}

\author{
Yasuhiro NAKA*3, Akihiro YAGUCHI, \\ Ryosuke KIMOTO and Takashi MIWA \\ ${ }^{* 3}$ Hitachi, Ltd., Meckanical Engineering Reserch Laboratory, \\ 832-2 Horiguchi, Hitachinaka-shi, Ibaraki, 312-0034 Japan
}

\begin{abstract}
We developed a method to evaluate the life of the wiring in non-solder mask defined (NSMD) solder joint pads in an LSI package. Generally, in a thermal cycling test, a package with NSMD pads has a longer life than a package with conventional pads. However, the load on the wiring in the pad in package with NSMD pads is greater than that in a package with conventional pads, so the joints with the NSMD pads may become disconnected due to failure of the wiring, not the solder. A method is thus needed to evaluate the life of the wiring. We have developed a method to measure the fatigue strength of the wiring, and we have developed a method to evaluate the life of the wiring by the finite element method. The life of the wiring in the pad is predicted by the analyzed plastic strain in the wiring and the measured fatigue strength data.
\end{abstract}

Key Words: Life Prediction, Fatigue, Finite Element Method, LSI Package, NSMD, Copper, Wiring

\section{1. 緒}

近年の電子情報機器内部の実装の高密度化に伴い, 搭載される半導体パッケージは小型化し，はんだ接続 部の微細・狭ピッチ化が進んでいる.ささら，自動車 搭載部品に代表される過酷環境下での使用機会の増加 により，はんだ接続部への負荷は増大する傾向にある. そのため, はんだ接続部の長期信頼性確保が半導体製 品の最重要課題となっている. 温度サイクルに対する はんだ接続部の疲労寿命を向上させる構造として，図 1 (@に示したような, NSMD (Non Solder Mask Defined）接続と呼ばれる構造が知られている12。 。 かし，NSMD 接続ではパッケージ基板への負荷が大 きく，はんだが破壊する前に接続パッドから引出され た配線 (パッド引出し配線) が断線する場合がある. そのため, 配線部の疲労強度評価手法の確立が課題と なっている，そこで, 配線の疲労強度試験力法を考案 して，有限要素法による解析も併用した配線部の信頼 性評価手法の検討を行った。

* 原稿受付 2005 年 4 月 21 日.

*1 正員, (株) 日立製作所機械研究所(昰312-0034 ひたちなか 市堀口 832-2).

*2 (株) ルネサステクノロジ生産本部(画187-8588 小平市上水 本町 5-20-1).

E-mail : yasuhiro.naka.pt@hitachi.com

\section{NSMD 接続部の概要}

図 1 (b)には, 従来から広く用いられている SMD (Solder Mask Defined) 接続部を示寸. この SMD 接 続部では, 接続パッドの端部がソルダレジストで覆わ れるのに対し, 図 1 (にに示した NSMD 接続部では, パッド全体とパッドから引出された配線の一部がソル ダレジストで覆われることなく露出する．そのため,

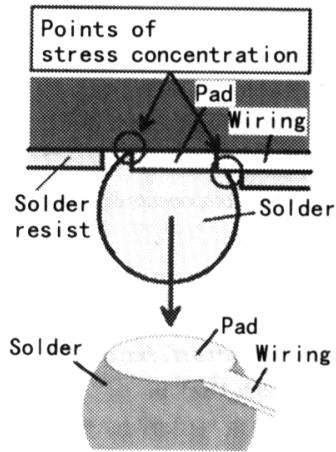

(a) NSMD

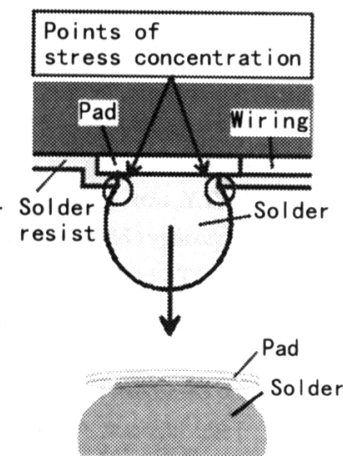

(b) SMD
Fig. 1 Comparison of structures of NSMD (Non solder mask defined) with SMD 
SMD 接続部では、はんだはソルダレジストと接する 部分にくびれを有する形状となるのに対し，NSMD 接続部では、はんだがパッドと配線にくい込んだ形状 で接続される. NSMD 接続部が SMD 接続部よりも 長寿命となる理由は，次のように考えられる．温度サ イクル負荷が作用した場合, SMD 接続部では前述の はんだのくびれ部分に応力が集中する.これに対し， NSMD 接続部では, 基材（基板樹脂材料）部やパッ ド引出し配線部が断線する事例 听あることでも明ら かなように，応力集中部ははんだ部だけでなく基材部 やパッド引出し配線部にも存在する。すなわち,

NSMD 接続部では，それらの部位に応力が分散され る結果, SMD 接続部の場合よりも長寿命になると考 えられる.しかし、NSMD 接続部の信頼性を確保す るためには，基材破壊，パッド引出し配線破壊をも考 虑した信頼性評価が必要となる.さらに、はんだの破 壊についても, NSMD 接続部の場合では, SMD とは き裂進展の経路が異なる ことが明らかになってい る.そのため, NSMD 接続部を採用した製品の信頼 性を検討寸る場合には，実機による信頼性試験を行っ ているのが現状である. しかし, 試験には多くの時間 を必要と寸るため，製品の設計段階から寿命が予測で きる新たな部価手法の確立が必要である，そこで本報 では，NSMD 接続部のパッド引き出し配線の強度評 価手法を提案し，その妥当性について検討した。

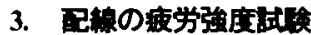

3.1 红誒方法 配線の疲労強度デー夕を取得す るための試験力法として，表面に配線を形成した有機 基板を作製し， 3 点曲げ試験を行った. 図 2 に, 試験 片の構造を示寸。試験片配線部の構造は, 実機パッケ ージと近い構造とした. 基板は, 幅 $3 \mathrm{~mm}$, 厚さ 0.2 $\mathrm{mm}$ の日立化成製 $\mathrm{E} 679 \mathrm{~F}$ 材で，その上部に形成した 配線は, 厚さ $0.012 \mathrm{~mm}$ の電解銅䇤上に, Cu を電解 めっきした二層構造である. 表 1 に示すように，配線

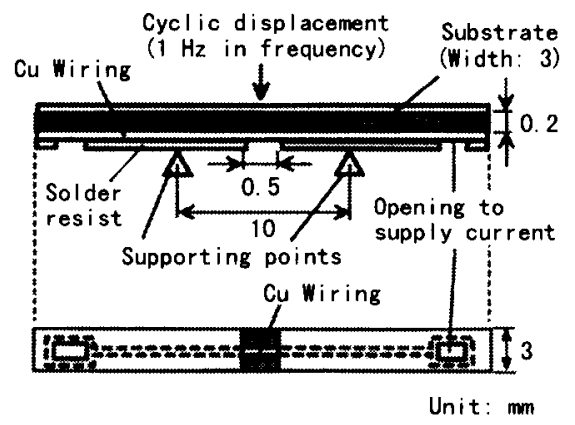

Fig. 2 Diagram of bending fatigue test for wiring
の幅，厚さの組合せとして5通り作製した。実機パッ ケージのパッド引出し配線の断線は，はんだとの接合 部の潗中部（特異場）で発生する。これを評価す るため, 試験片配線部にも実機と相似な応力特異場が 形成されるよう, 配線上に中央部が $0.5 \mathrm{~mm}$ 間隔で開 口するようにソルダレジストを形成し，さらに，その 開口部の配線上に, パッケージの接続パッドと同様に $\mathrm{N}$ と Au の電解めっき（Ni/Auめっき）を施した（図 2 および次節，図 4 参照. 応力分布が相似な場合, 特異点から同一距離離れた位置のひずみの值を相対比 較することで，比較的簡便に信賴性評価ができるため である. NvAuめっきは, Ni を成膜した後に $\mathrm{Au}$ を形 成したもので, NiとAuの厚さの比は, どの条件にお いても, およそ 9:1 とした. ただし，その総厚は， 表1に示したように，各条件で異なる。これは，製造 上の問題で意図せずに生じた差異である.

3 点曲げは, 図 2 に示したように, 支点間距離を $10 \mathrm{~mm}$ とし, その中央部に一定の片振り変位振幅を 周波数 $1 \mathrm{~Hz}$ で与えた. 試験中, 配線に定電流を流し， その抵抗を測定することにより断線の検出を行った。

図3に，その抵抗の測定例を示卞。断線した全ての試 験片において，図3の例のように，抵抗は徐々に増加 するのではなく，急激な変化を示した．しかし，金属 材料が常温の疲労試験て脆性破壊する現象は考え難い ため，実際には，抵抗変化が生じていない繰返し数か らき裂が発生，進展し，完全破断に近い状態までき裂

Table 1 Specifications of samples for bending tests

\begin{tabular}{|c|c|c|c|}
\hline No. & $\begin{array}{c}\text { Width of } \\
\text { wiring } \\
(\mu \mathrm{m})\end{array}$ & $\begin{array}{c}\text { Thickness } \\
\text { of wiring } \\
(\mu \mathrm{m})\end{array}$ & $\begin{array}{c}\text { Thickness of } \\
\text { Ni/Au plate } \\
(\mu \mathrm{m})\end{array}$ \\
\hline 1 & 100 & 25 & 18 \\
\hline 2 & 150 & 25 & 11 \\
\hline 3 & 200 & 25 & 21 \\
\hline 4 & 150 & 15 & 15 \\
\hline 5 & 150 & 35 & 14 \\
\hline
\end{tabular}

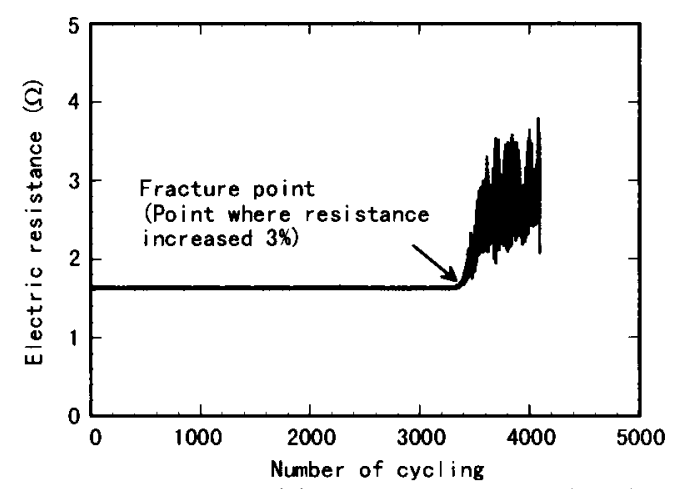

Fig. 3Typical change of electric resistance in sample wiring 
が進展した点で初めて抵抗変化として検出されたもの と考える. 測定した抵抗は, 試験片両端の電源供給用 端子 (図 2 参照) 間の全抵抗だったため, き裂進展に 伴う局所的な抵抗変化は検出できなかったものと考え られる.ここでは, 抵抗值が初期の值に対して $3 \%$ ま で増加した点を断線と定義し, 統一を図った。なお, 変位振幅が $0.25 \mathrm{~mm}$ を超えると, いずれの試験片に おいても基材部にクラックが生じることが確認された. この場合，基材部の破壊を起点として配線が断線した 可能性が考えられるため, 配線の疲労強度データから は除外した。

3.2 試験結果と考察 図 4 に, 破壊した試験片 の断面写真の一例（表 1 の No. 2, 変位振幅 $0.2 \mathrm{~mm}$ ) を示す.この例のように，いずれの試験片仕様，試験 条件に㧍いても, 破壊は応力集中場である $\mathrm{Cu}$ と $\mathrm{N} \mathrm{i} / \mathrm{Au}$ めっきとの接合端部を起点として発生した. こ の点は, ソルダレジスト端部でもある. 図 5 に, 配線 厚さが等しく, 配線幅と $\mathrm{N} / \mathrm{Au}$ めっき厚さが異なる試 験片（表1のNo.1〜3）について試験結果を示す. 縦軸は, 試験片中央部の変位, 横軸は, 断線に到るま での繰返し数 (寿命) とした．図 5 のように縦軸を変 位として整理すると，配線幅，あるいは NiAu めっき 厚さの違いによって，同一変位におけりる寿命が異なる ように見える. 図6には, 配線幅が等しく, 配線厚さ と Ni/Auめっき厚さが異なる場合（表 1 の No. 2，4， 5 の試験片）の試験結果を示した. この場合には，図 5 と異なり, 配線厚さ, Ni/Au めっき厚さ依存性は明 確に見えておらず，ほぼ同一直線上に試験結果が分布 した. この図 5 と図 6 の試験結果の違いについては, 5 章で, 解析結果に基づき考察する.

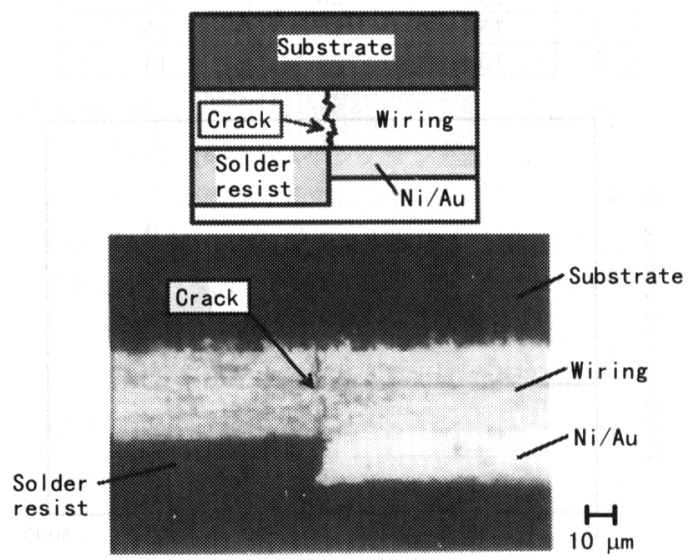

Fig. 4 Typical fatigue failure in wiring on bending sample

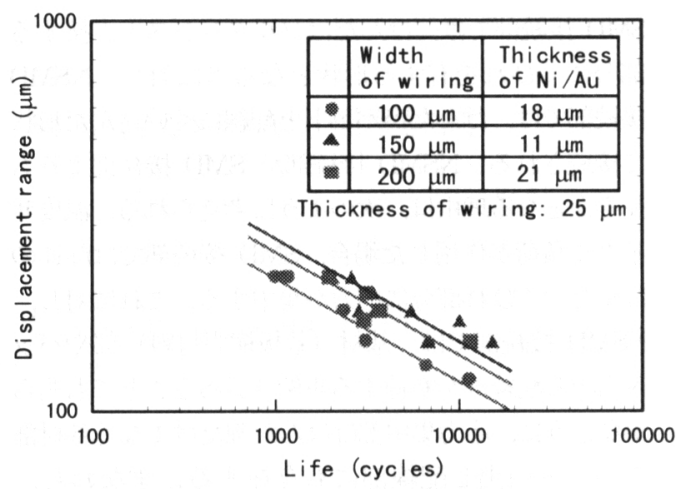

Fig. 5 Results of bending tests using samples with width of wiring in range from 100 to $200 \mu \mathrm{m}$

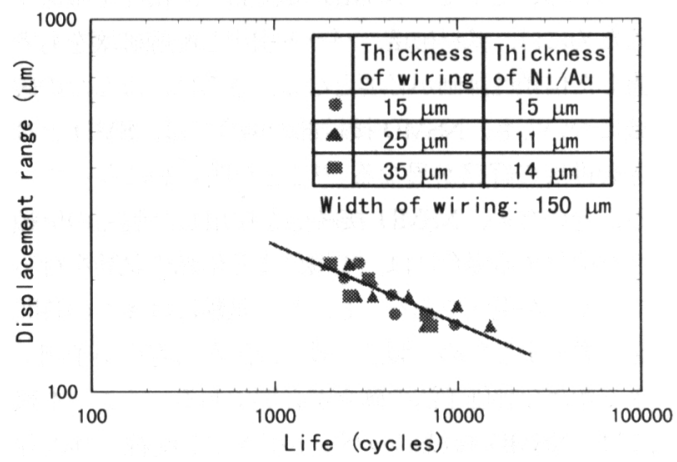

Fig. 6Results of bending tests using samples with thickness of wiring in range from 15 to $35 \mu \mathrm{m}$

\section{4. 実機の温度サイクル試験}

$4 \cdot 1$ 試験方法 曲げ疲労試験データと比較する ため, NSMD 接続部を有するパッケージに対して温 度サイクル試験を実施した. 種々のパッケージ構造で, 温度サイクルの温度範囲が異なる場合でも評価可能な 疲労強度評価手法を確立することが目的であるため, 以下で述べる 3 種の異なるパッケージに対し，それぞ れ異なる試験条件で試験し，評価手法の検討を行った。 図 7 に, パッケージ構造とその接続形態を図示し, 表 2 に, 各パッケージの接続部の構造仕様をまとめる. パッケージ A と B は，FR-4製実装基板の両面に，パ ッケージ C は片面にのみ接続した. パッケージ C の 基板には，厚さ $2 \mathrm{~mm}$ のアルミ板を接着した。接続は んだ材料は, パッケージ A と C が $\mathrm{Sn}-3.5 \mathrm{Ag}-0.75 \mathrm{Cu}$, パッケージ B が $60 \mathrm{Sn}-40 \mathrm{~Pb}$ 共晶である. チップの接

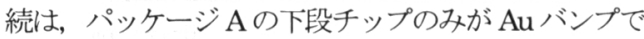
フリップチップ接続され，チップと基板間にアンダー 


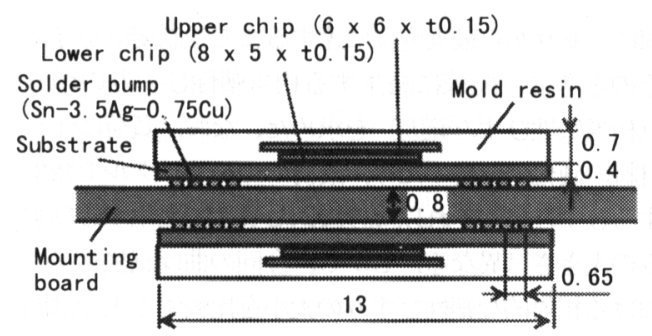

(a) Package $\mathrm{A}$

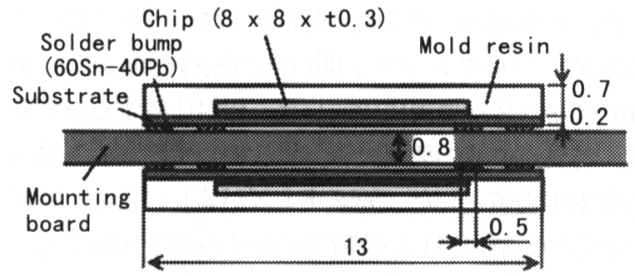

(b) Package B

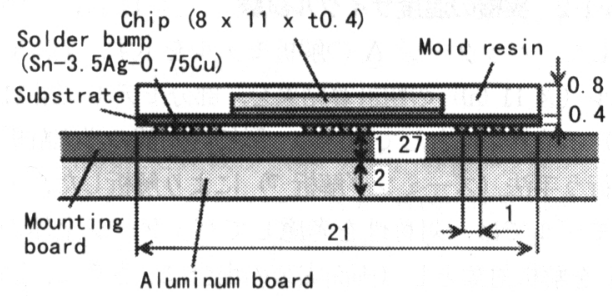

(c) Package C

Uhit: $m$

Fig. 7Diagram of packages for thermal cycling test

Table 2 Specifications of solder joints in packages

\begin{tabular}{|c|c|c|c|c|c|}
\hline No. & Package & $\begin{array}{c}\text { Diameter } \\
\text { of pad } \\
(\mathrm{mm})\end{array}$ & $\begin{array}{c}\text { Width of } \\
\text { Wiring } \\
(\mu \mathrm{m})\end{array}$ & $\begin{array}{c}\text { Thickness } \\
\text { of Wiring } \\
(\mu \mathrm{m})\end{array}$ & $\begin{array}{c}\text { Height of } \\
\text { solder bump } \\
(\mathrm{mm})\end{array}$ \\
\hline 1 & A & 0.35 & 100 & 15 & 0.28 \\
\hline 2 & A & 0.35 & 100 & 15 & 0.050 \\
\hline 3 & B & 0.30 & 150 & 25 & 0.050 \\
\hline 4 & C & 0.48 & 210 & 25 & 0.40 \\
\hline
\end{tabular}

フィルが挿入されている. 他は全てダイボンド材でフ エイスアップ接続され, ワイヤボンディングで結線さ れている，温度サイクルは, パッケージ A に対して は-25から $125^{\circ} \mathrm{C}$, パッケージ B と C は- 55 から $125^{\circ} \mathrm{C}$ の条件で, 周期はいずれの場合も 20 分とした. 各仕 様のサンプル数は 20 個づつとた. 接続部の電気的 導通に 1 筒所でも異常が発生した場合を不良発生と考 え, 不良発生したパッケージ数の累積率が $50 \%$ とな ったサイクル数を各パッケージの寿命と定義した.

$4 \cdot 2$ 試験結果 表 3 に, 試験結果を示す. 不良 が発生したサンプルの内, 各仕様数個づつ断線部断面 観察を実施したところ, いずれもパッド引出し配線部 にき裂が確認された.これらは, いずれも搭載チッ
プコーナ一部近傍に位置するパッドから，最寄のパッ ケージコーナー部の方向へ引出された配線であった. 図 8 に, パッケージ A の断線部の断面写真を示す. この例のように, いずれのパッケージも，Cu と $\mathrm{Ni} / \mathrm{Au}$ めっき接合端部の, 3 点曲げ試験片の場合と同 位置にクラックが認められた.これは，同試験が実機 を模擬できていることを示している. なお, 図 8で, き裂は配線部だけでなく基材部にも認められる. しか し，この基材へのき裂は，配線が断線した後に発生し たき裂と推定される. その理由は, 同じくチップコー ナ一部近傍に位置する引出し配線のないパッドでは, 基材部の応力を解析したところ, 引出し線がある場合 よりも大きかったにもかかわらず，基材のき裂は認め られなかったためである。

Table 3 Results of thermal cycling tests

\begin{tabular}{|c|c|c|c|}
\hline No. & Package & $\begin{array}{c}\text { Temperature } \\
\text { range }\left({ }^{\circ} \mathrm{C}\right)\end{array}$ & $\begin{array}{c}\text { Life time to fail } 50 \% \\
\text { samples (Cycles) }\end{array}$ \\
\hline 1 & $\begin{array}{c}\text { A } \\
\text { (0.28 mm in bumpheight) }\end{array}$ & -25 to 125 & 600 \\
\hline 2 & $\begin{array}{c}\text { A } \\
\text { (0.050mminbumpheght) })\end{array}$ & -25 to 125 & 1000 \\
\hline 3 & B & -55 to 125 & 800 \\
\hline 4 & C & -55 to 125 & 1100 \\
\hline
\end{tabular}

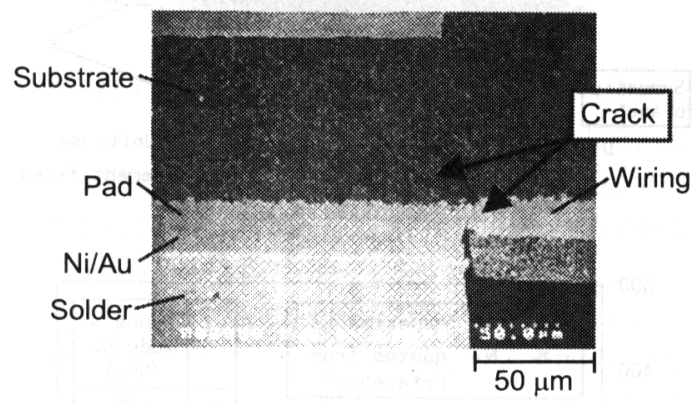

Fig. 8 Fatigue failure in wiring of package A

\section{5. 解析による配線疲労強度評価手法の検討}

\section{$5 \cdot 1$ 解析方法}

$5 \cdot 1 \cdot 13$ 点曲け試験 配線の曲げ疲労試験データ から, 実機パッケージのパッド引出し配線寿命を解析 で評価する手法を検討した．比較的簡便に評価可能な 手法として, 以下で述べるように, 配線部の塑性ひず みを解析し, その值を相対比較して評価する手法を提 案する. 図 9 に, 曲げ試験の解析モデルを示す. 支点 間の構造のみモデル化し, さらに, 対称性を考慮して その $1 / 4$ のみをモデル化した. 刘称面の法線方向変位 は拘束とした． Cu と $\mathrm{N} / \mathrm{Au}$ めっを弾塑性材料と考 
えて, 有限要素法で弾塑性解析を行った. Cu の応力ひずみ特性は, 上記試験片と同様の, 厚さ $12 \mu \mathrm{m} の$ 電解銅䇴を $70 \times 5 \mathrm{~mm}$ の短冊状に形成し, これを引張 試験で求めた。試験機は, MTS 社製 TYTRON 250 を 使用した. 図 10 に, 取得した $\mathrm{Cu}$ の応力てずみ特性 を示す. Nv/Au めっきの特性は, 厚さ比で約 $90 \%$ 占 める $\mathrm{Ni}$ の特性で代表させることにし, 図 10 中に示し た純 $\mathrm{Ni}$ バルク材の文献值》とした. $\mathrm{Cu}$ と $\mathrm{Ni}$ のポア ソン比は 0.3 を仮定した. 配線内の初期残留応力 (真 性応力 5) と熱応力の和）の影響は無視できると仮定 した.一般に, 金属の低サイクル疲労現象においては, 残留応力は負荷の繰返しに伴って緩和され，その影響 はほとんどない㫙めである. 初期残留応力によって 材料に初期欠陷が存在する場合には, 寿命に影響する 可能性があるが，今回その影響は無視できると仮定し た. 基板とソルダレジストの材料特性は弾性を仮定し, メーカーからの提供值として, 表 4 の值を使用した. 解析では, 眓9に示したように, 負荷点の試験片中央

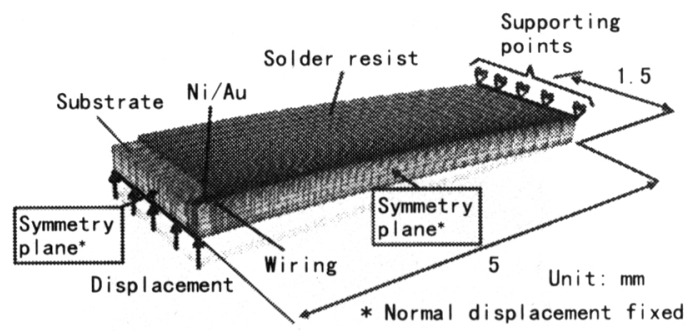

Fig. 9 Analysis model for bending test

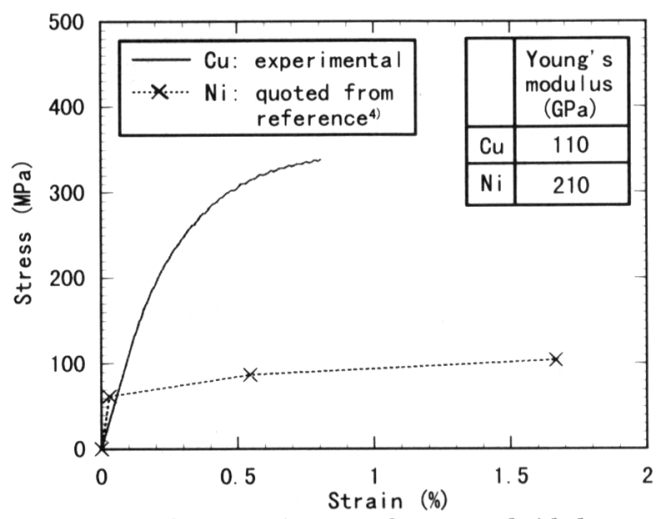

Fig. 10Stress-strain curve of oopper and nickel

Table 4 Elastic constants of substrate and solder resist

\begin{tabular}{|c|c|c|}
\hline Component & $\begin{array}{c}\text { Young's } \\
\text { modulus } \\
(\mathrm{GPa})\end{array}$ & $\begin{array}{c}\text { Poisson's } \\
\text { ratio }\end{array}$ \\
\hline Substrate & 30 & 0.2 \\
\hline Solder resist & 25 & 0.45 \\
\hline
\end{tabular}

部に, ゼロから最大変位に達寸るまで強制変位を与え, そのときに, 配線に発生する相当塑性ひずみの増分

（相当塑性ひずみ範用）を求めた，なお，負荷に伴う 材料の硬化の影響のため, 最初の 0.5 サイクルで発生 するひずみと, それ以降の繰返し負荷で発生するひず みの大きさは異なる.しかし, 今回の曲げ試験結果に おける相対的な塑性ひずみの大小を比較する上では問 題ないと考え, ここでは, 0.5 サイクルまでの解析と した. 特異場のひずみは, 要素サイズに大きく依存す るため, ソルダレジスト開口部の配線の要素は, 20 $\mu \mathrm{m}$ 立方の 2 次要素に統一した. 相対比較するひずみ は, 特異点位置の要素で発生する相当塑性ひずみ範囲 の要素平均値とした. 要素サイズが等しいため, 特異 点からの距離が等しい位置でのひずみ值を比較するこ とと同義である.

$5 \cdot 1 \cdot 2$ 実機の温度サイクル試験 図 11 に, 一例 として, パッケージ A の解析モデルを示す. 全体モ デル (図 11 (a) の粗計算結果を, 部分モデル (図 11 (b)）の境界条件として取込み, 微細評価部の詳細解析 を行う手法（ズーミング解析 わ）により解析した．全 体モデルでは，対称性を考慮してパッケージ全体の $1 / 4$ 老解析対象とし (両面実装の場合は, さらに, 図 11 (ఏのように, 実装基板の厚さの $1 / 2$ のみを解析対象 とした）, 対称面の法線方向変位は拘束とした.

パッドとパッド引出し配線の $\mathrm{Cu}$ は, 図 10 の特性值 を用いた（ポアソン比は 0.3 , 線膨張倸数は $17 \times 10^{6}$ $\mathrm{K}^{-1}$ を仮定）。Cu の物性の温度依存性は, $-55 \sim 125^{\circ} \mathrm{C}$ の範用では無視できると仮定した. Cu とはんだの間

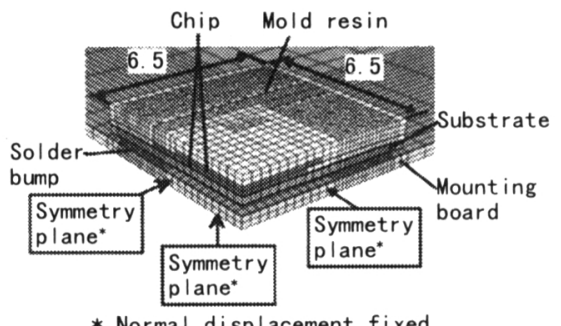

* Normal displacement fixed

(a) Whole model

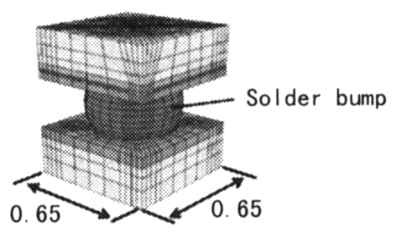

(b) Local model

Uhit: $m$ m

Fig. 11 Two-step (zooming) analysis models of package A 
Table 5 Elastic-plastic constants of solder bump

\begin{tabular}{|c|c|c|c|c|c|c|}
\hline Material & $\begin{array}{c}\text { Temperature } \\
\left({ }^{\circ} \mathrm{C}\right)\end{array}$ & $\begin{array}{c}\text { Young's } \\
\text { modulus } \\
(\mathrm{GPa})\end{array}$ & $\begin{array}{c}\text { Poisson's } \\
\text { ratio }\end{array}$ & $\begin{array}{c}\mathrm{CTE}^{*} \\
\left(10^{-6} \mathrm{~K}\right)\end{array}$ & $\begin{array}{c}\text { Yield } \\
\text { stress } \\
(\mathrm{MPa})\end{array}$ & $\begin{array}{c}\text { Strain } \\
\text { hardening exponent } \\
(\mathrm{GPa})\end{array}$ \\
\hline \multirow{3}{*}{$\begin{array}{c}\text { 60Sn-40Pb } \\
\text { (Package B) }\end{array}$} & -60 & 31 & 0.3 & 26 & 39 & 1.1 \\
\cline { 2 - 7 } & 0 & 30 & 0.3 & 26 & 22 & 0.62 \\
\cline { 2 - 7 } & 25 & 29 & 0.3 & 26 & 16 & 0.47 \\
\cline { 2 - 7 } & 90 & 23 & 0.3 & 26 & 8.1 & 0.24 \\
\hline \multirow{3}{*}{$\begin{array}{c}\text { Sn3.5-Ag-0.75Cu } \\
\text { (Package A, C) }\end{array}$} & -150 & 16 & 0.3 & 26 & 3.2 & 0.10 \\
\cline { 2 - 7 } & -15 & 41 & 0.35 & 23 & 52 & 0.98 \\
\cline { 2 - 7 } & 71 & 0.35 & 23 & 38 & 0.69 \\
\cline { 2 - 7 } & 125 & 40 & 0.35 & 23 & 33 & 0.42 \\
\hline
\end{tabular}

* Coefficient of thermal expansion

に介在する $\mathrm{N} / \mathrm{Au}$ めっきは，モデルを簡略化するため に省略し, N/Au 部分もはんだとした. 省略によって 発生する誤差量を把握するため, Ni/Au めっきをモデ ル化した場合のパッド引出し配線部のひずみも解析し たところ，Ni/Au を省略した場合のひずみに対して, $5 \%$ 程度の増加率にとどまった. Ni/Au は厚さ $10 \sim 15$ $\mu \mathrm{m}$ とはんだと比較して薄いため, 影響が少なかった と考えられる. パッケージ B の 605n-40Pb 共晶はん だの弾塑性特性は, 文献 邓の繰返しねじり試験による 測定值を参照し（せん断応力, せん断ひずみの測定デ 一タから, 垂直応力, 垂直ひずみ一の変換にはミーゼ スの相当応力, 相当ひずみの式を使用), さらにこれ を 2 直線で近似した表 5 に示した值9を用いた。はん だに発生する塑性ひずみは十分大きいため, 2 直線近 似を用いても問題ないと考えたためである. パッケー ジ A, C の Sn-3.5Ag-0.75Cu はんだについては, 共晶 はんだと同様の方法で実測した值に基づき, 表 5 に示 した 2 直線近似值を用いた. これらの速度依存性が大 きいはんだの特性としては, 温度サイクルの周期が 20 分（周波数 $8.3 \times 10^{4} \mathrm{~Hz}$ ) であることを考虑して, 試験周波数 $10^{-4} \mathrm{~Hz}$ のデータを採用した. 表 5 の物性 值は，周波数 $10^{-4} \mathrm{~Hz}$ の場合のクリープの影響が含ま れた值である. そのため, これとほぼ周波数が等しい 温度サイクル試験については, 表 5 の物性值を使用し て解析を行うことで, 簡便にクリープの影響が考慮さ れた解が得られる. 配線とはんだ以外の材料について は, $-55 \sim 125^{\circ} \mathrm{C}$ 範囲では温度依存性のない弾性材料 と仮定し，表 6 に示寸值を用いた. なお，パッケージ A のチップ接続バンプは，周囲のアンダーフィル材と 比較して体積が小さいため, モデルでは省略した. ボ ンディングワイヤもモデルでは省略している.

はんだが高温で溶融されて接続されることを考慮し て, 温度サイクルの最高温度での応力をゼロと仮定し, そこを解析の起点として最低温度に達するまでの相当
Table 6Elastic constants of main components in packages

\begin{tabular}{|c|c|c|c|}
\hline Component & $\begin{array}{c}\text { Young's } \\
\text { modulus } \\
(\mathrm{GPa})\end{array}$ & $\begin{array}{c}\text { Poisson's } \\
\text { ratio }\end{array}$ & $\begin{array}{c}\mathrm{CTE}^{*} \\
(\mathrm{ppm} / \mathrm{K})\end{array}$ \\
\hline Chip & 190 & 0.07 & 3 \\
\hline $\begin{array}{c}\text { Mounting } \\
\text { board }\end{array}$ & 21 & 0.2 & $\mathrm{~A}, \mathrm{~B}: 15, \mathrm{C}: 19$ \\
\hline Substrate & $\mathrm{A}: 31, \mathrm{~B}: 20, \mathrm{C}: 22$ & 0.2 & $\mathrm{~A}: 12, \mathrm{~B}: 14, \mathrm{C}: 15$ \\
\hline Mold resin & $\mathrm{A}, \mathrm{B}: 21, \mathrm{C}: 18$ & 0.2 & $\mathrm{~A}, \mathrm{~B}: 9, \mathrm{C}: 12$ \\
\hline Under-fill & 6 & 0.3 & 26 \\
\hline Die bond & 0.5 & 0.3 & 120 \\
\hline Al board & 70 & 0.3 & 23 \\
\hline
\end{tabular}

*CTE: Coefficient of thermal expansion

塑性ひずみ範囲を求めた. 曲げ試験のデータと比較す るため, ここでも 0.5 サイクルまでの解析とした. ま た, 部分モデルのパッド引出し配線は $20 \mu \mathrm{m}$ 立方の 2 次要素による分割で統一し, 特異点位置の要素で発生 する相当塑性ひずみ範井の要素平均值を求めた.

以上のようにして求められた 3 点曲げ試験と温度サ イクル試験で配線に発生する塑性ひずみを相対的に比 較することにより, 簡便に寿命評価を行うことが可能 かどうかを以下で検討した.

$5 \cdot 2$ 解析結果と考察 図 12 (a), 曲げ試験時に 発生する塑性ひずみ分布の解析例を示す. また, 図 12 (b)には, 温度サイクル試験においてパッケージの パッド引出し配線に発生する塑性ひずみ分布解析例を 示す. 図 12(a)のように, 曲げ試験を模擬した解析結 果では, N $\mathrm{A} \mathrm{Au}$ めっきと接合端部で配線に最大ひず みが発生した. 一方, 図 12(b)のように, パッケージ の温度サイクル試験では, はんだとの接合端部で配線 のひずみが最大となった. いずれも, 最大ひずみの位 置は, 実際のクラック発生位置と一致した. なお, 配 線部の応力状態は, 曲げ試験片, パッケージいずれの 場合も, 配線に平行な方向の応力を主とする 1 軸応力 状態に近い状態であった。

図 5,6 に示した試験結果を, 縦軸を変位ではなく, 

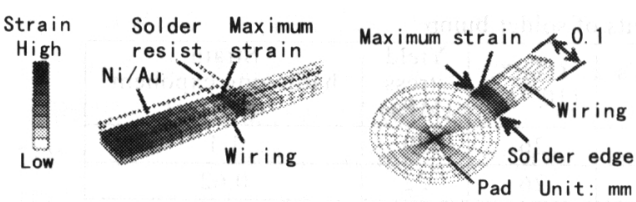

(a) Bending sample

(b) Package A

Fig. 12Distribution of plastic strain in wiring

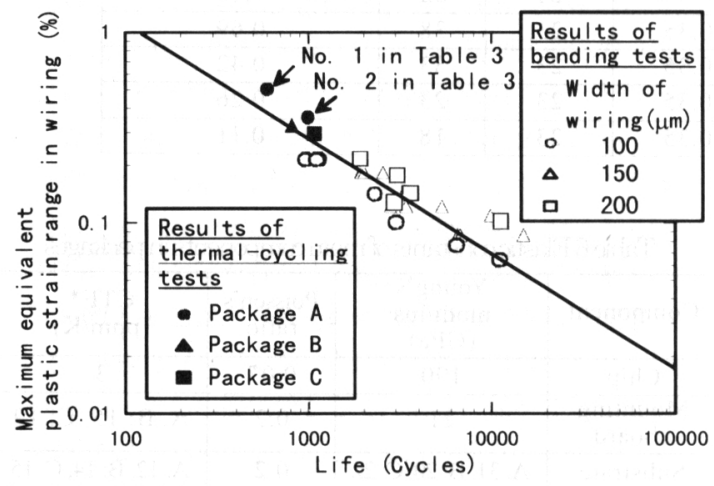

(a) Data of packages and bending samples

with width of wiring in range from 100 to $200 \mu \mathrm{m}$

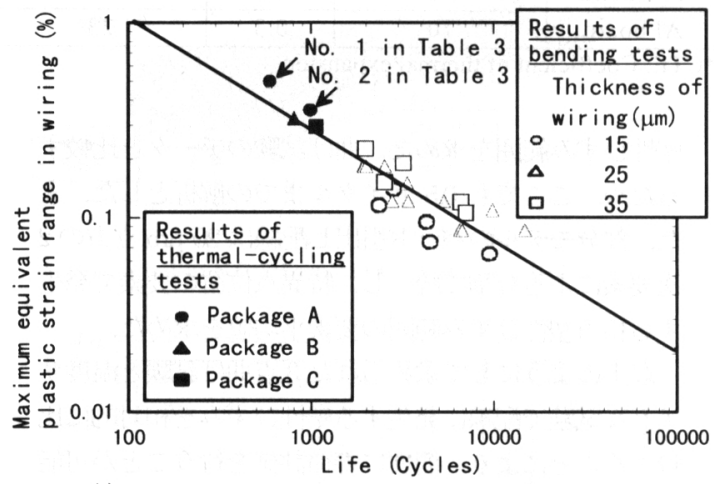

(b) Data of packages and bending samples

with thickness of wiring in range from 15 to $35 \mu \mathrm{m}$

Fig. 13Relation between plastic strain in wiring and life

配線の最大相当塑性ひずみ範用の解析值を用いて整理 し直したグラフを図 13 に示す。また, 温度サイクル 試験でパッケージのパッド引出し配線に発生する塑性 ひずみの解析値と寿命の関係も同グラフ上にプロット した. 変位で整理した図 5 では, 配線幅, Ni/Auめつ き厚さ依存性が見られたが，塑性ひずみで整理した図 13 (a)の曲げ試験のデータは, 配線幅, $\mathrm{N} / \mathrm{Au}$ 厚さに 大きく依存せず，ほぼ同一直線上に分布することがわ かる. 配線厚さ, Ni/Au めっき厚さが異なる場合の図 6 のグラフについても塑性ひずみで整理したところ, 図 $13(b)$ の曲け試験デー夕は, ほぼ同一直線上に分布
した.これは, 図 13 (a)直線とほぼ一致する.さら に, 図 13 に示したパッケージの温度サイクル試験の データも, 曲げ試験データが分布した直線と，ほぼ同 一直線上に分布した. このことから，パッド引出し配 線の塑性ひずみを解析し，これと曲げ疲労試験の塑性 ひずみと寿命のデータを比較することにより，実機の 温度サイクル試験での寿命を簡便に予測することが可 能であると考えられる.

変位で整理した図 5 において, 配線幅, Nv/Au めっ き依存性が見られた理由は, 以下のように考えられる. 図 14 に, 配線のひずみの, 配線幅と $\mathrm{N} / \mathrm{Au}$ めっき厚 さ依存性を解析した結果を示す. 図 14 から，ひずみ の配線幅依存性は幅 100２00 $\mu \mathrm{m}$ の範囲では小さく, $\mathrm{N} \mathrm{A} / \mathrm{Au}$ めっき厚さへの依存性の方が大きいことがわか る. したがって, 図 5 の分布は, NiAu めっき厚さの 差異の影響が表れたものと考えられる. 一方, 図 15 には, 配線ひずみの配線厚さと NiAu めっき厚さ依存 性を示寸. 配線厚さの変化に対しては, ひずみが変化

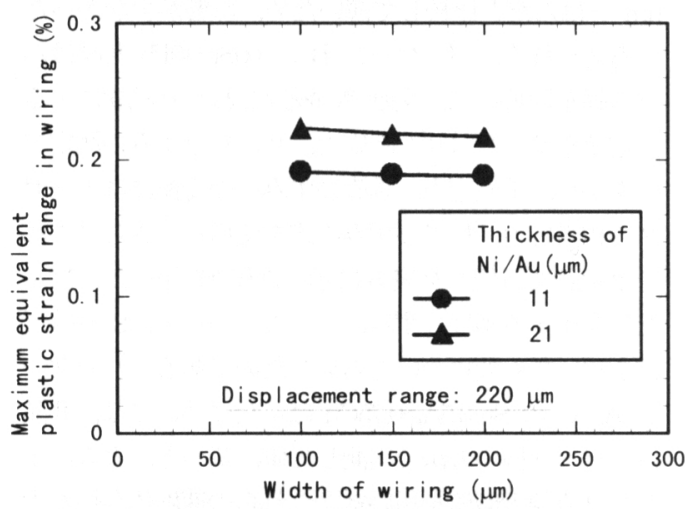

Fig. 14Dependenoe of strain in wiring on width of wiring and thickness of $\mathrm{N} / \mathrm{Au}$

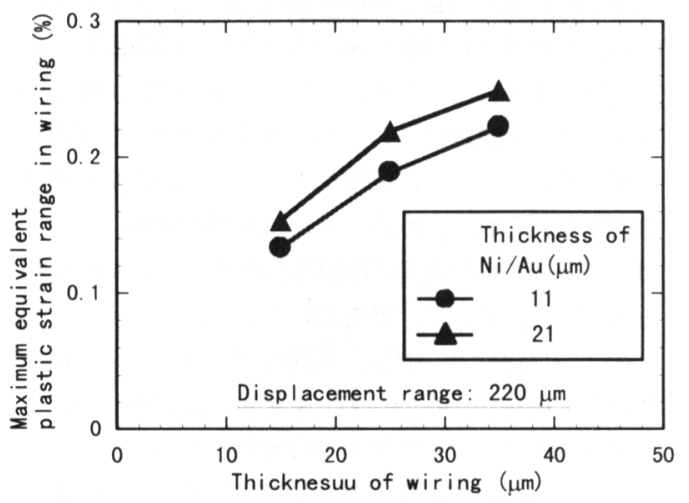

Fig. 15Dependenoe of strain in wiring on thickness of wiring and $\mathrm{N} / \mathrm{Au}$ 
することを示している．しかし，配線厚さの影響が $\mathrm{N} / \mathrm{Au}$ めっき厚さの影響によって相殺されたため, 図 6 のプロット点は, 配線厚さ, N/Au めっき厚さに依 存しない同一直線上に分布したと考えられる.

塑性ひずみで整理した図 13 (ににおいて, 最も配線 幅の小さい幅 $100 \mu \mathrm{m}$ の場合のデータは，同じ塑性ひ ずみの值に対する寿命が, 幅 $150,200 \mu \mathrm{m}$ の場合の 寿命よりも若干短くなる傾向が認められる. また, 図 13 (b)では, 最も厚さの薄い厚さ $15 \mu \mathrm{m}$ のデータが,

厚さ $25,35 \mu \mathrm{m}$ のプロット点から若干外れる傾向が 認められる. これらのことから, 配線幅 100〜200 $\mu \mathrm{m}$, 厚さ $15 \sim 35 \mu \mathrm{m}$ の範用を著しく逸脱する場合には, 今回得られたひずみと寿命の関係から外れる可能性が 考えられるので注意が必要である. しかし, パッケー ジのパッド引出し配線は，ほとんどの場合この配線幅， 厚さの範用内なので, 実用上は問題ないと考える.

\section{6. 結}

NSMD（Non Solder Mask Defined）はんだ接続用パ ッドを有する半導体パッケージの，パッド引出し配線 疲労強度評価手法について検討し, 以下の結論を得た。 (1) 曲げ試験による配線の疲労試験方法を考案し，配 線の寿命データを取得した.

(2) 弾塑性解析で得られる曲げ試験で配線に発生する 塑性ひずみと, 寿命の関係は, 配線の構造寸法によ らず，同一直線上に分布することを明らかにした (配線幅 $100 \sim 200 \mu \mathrm{m}$, 厚さ $15 \sim 35 \mu \mathrm{m}$ の場合).

(3) 温度サイクル試験で実機パッケージのパッド引出 し配線に発生する塑性ひずみを解析し，これと曲げ 疲労試験で得られた塑性ひずみと寿命の関係を比較 することにより，実機パッケージパッド引出し配線 の寿命を実用上十分な精度で簡便に予測できること を明らかにした（配線幅 100～200 $\mu \mathrm{m}$ ，厚さ 15〜35 $\mu \mathrm{m}$ の場合）。

\section{7 考支献}

1) Mawer, A, Vo, N., Johnson, Z and Lindsay, W. Proc. 49th ECTC(19996), pp. 118-124.

2) Naka, Y., Yaguchi, A, Kimoto, R. and Miwa, T., Proc. 14th Microelectronics Symposium(2004-10), pp. 313-316.
3) Tanie, H., Terasaki, K and Naka, Y., Proc. 17th Computational Mechanics Conference(2004-11), pp. 791792.

4) Atlas of Stress-Strain Curves, ASMInternational(2002). 5) Maki, K, Applied Physics, Vol. 57, No. 12 (1998), pp. 1856-1867.

6) JSME ed, JSME Mechanical Engineers' Handbook, Fundamentals, Materials and Mechanics, (1994), p. 122 JSME.

7) Naka, Y., Saito, N. and Naito, T., Proc 14th Computational Mechanics Conference (2001-11), pp. 469470.

8) Kitano, M, Kawai, S. and Shimizu, K, Trans JEME, Series $A$ Vol 54, No. 505 (1988), pp. 1709-1715.

9) Naka, Y., Tanaka, N. and Naito, T., J. Japan Institute of Electronics Packaging, Vol7, No. 1 (2004), pp. 40-46. 